\title{
Implementasi Program Pemberdayaan Masyarakat Mandiri Perdesaan di Desa Ensaid Panjang Kecamatan Kelam Permai Kabupaten Sintang
}

\section{Implementation of the Independent Rural Community Empowerment Program in Ensaid Panjang Village, Kelam Permai District, Sintang Regency}

\author{
Gunawan', Mikael Mahin', Yudika Cahyana1, Desi Ratnasari2 \\ 1Jurusan Ilmu Administrasi, Fakultas Ilmu Sosial dan Ilmu Politik, Universitas Kapuas, Sintang, \\ Kalimantan Barat, Indonesia \\ ${ }^{2}$ Fakultas Keguruan dan Ilmu Pendidikan, Universitas Kapuas, Sintang, Kalimantan Barat, Indonesia
}

Disetujui: Nopember 2021; Direview: Desember 2021;Diterima: Desember 2021

\begin{abstract}
Abstrak
Tujuan penelitian ini adalah untuk memaparkan implementasi pembangunan jalan pada daerah pinggiran di Desa Ensaid Panjang, Kecamatan Kelam Permai, Kabupaten Sintang. Permasalahan pokok yang ditelaah dalam penelitian ini adalah bagaimana proses implementasi yang mencakup Perencanaan partisipatif, Pelaksanaan dan Pemeliharaan Hasil Pembangunan serta faktor-faktor yang mempengaruhi implementasi PNPM Mandiri Perdesaan di Desa Ensaid Panjang Kecamatan Kelam Permai meliputi Kesadaran Masyarakat, Organisasi Pelaksana dan Anggaran. Metode penelitian ini menggunakan pendekatan kualitatif. Pengumpulan data melalui tehnik observasi, wawancara, dan dokumentasi. Instrumen penelitian meliputi peneliti sendiri, panduan wawancara dan catatan lapangan. Selanjutnya rangkuman dari hasil wawancara dibahas dalam sebuah focussed group discussion. Hasil penelitian menunjukkan program ini pada umumnya sangat didukung dan diterima masyarakat, meskipun sumber daya masyarakat belum tersedia secara maksimal. Pelaksana program PNPM Mandiri masih kurang memperhatikan faktor cuaca, anggaran yang kurang memadai sehingga tidak bisa melaksanakan pelatihan teknis dan kekurangan anggaran untuk pemeliharaan. Namun secara umum Implementasi PNPM Mandiri Perdesaan Bidang Infrastruktur di Desa Ensaid Panjang telah berjalan dengan baik.
\end{abstract}

Kata Kunci: Pemberdayaan, Pembangunan Prasarana, Kemandirian

\begin{abstract}
The purpose of this study is to describe the implementation of road construction in suburban areas in Ensaid Panjang Village, Kelam Permai District, Sintang Regency. This study adopted a policy analysis method supported by in-depth interviews with the Head of the Sintang District Public Works Service, the Head of the Kelam Permai Sub-district, the Head of Ensaid Panjang Village and two community leaders. Furthermore, the summary of the results of the interviews is discussed in a focused group discussion. The results of the research showed that this program was generally very well supported and accepted by the community, although community resources were insuficient. In the physical implementation of infrastructure, there were still weaknesses such as planning that provide little attention to weather factors, inadequate budget for technical training and maintenance. However, in general, the implementation of PNPM Mandiri in Rural Infrastructure in Ensaid Panjang Village has been implemented efectively.
\end{abstract}

Keywords: Quality of Public Service, SIM, Polrestabes Bandung, Covid-19

How to Cite : Gunawan (2021). Implementasi Program Pemberdayaan Masyarakat Mandiri Perdesaan di Desa Ensaid Panjang Kecamatan Kelam Permai Kabupaten Sintang. PUBLIKAUMA: Jurnal Ilmu Administrasi Publik UMA, Vol. 9 (2):v33-43

${ }^{*}$ Corresponding author:

ISSN 2549-1660 (Print)

E-mail: pakgunawan1906@gmail.com

ISSN 2580-2011 (Online) 


\section{PENDAHULUAN}

Kemiskinan dan pengangguran merupakan masalah utama bangsa Indonesia. Kemiskinan di Indonesia dapat dilihat dari tiga pendekatan yaitu pendekatan kemiskinan alamiah, kemiskinan struktural, dan kesenjangan antar wilayah (Ferezagia, 2018; Zuhdiyaty \& Kaluge, 2017). Persoalan pengangguran lebih dipicu oleh rendahnya kesempatan dan peluang kerja bagi angakatan kerja di perdesaan. Upaya untuk menanggulangi harus menggunakan pendekatan multi disiplin yang berdimensi pemberdayaan. Pemberdayaan yang tepat harus memadukan aspek-aspek penyadaran, peningkatan kapasitas, dan pendayagunaan (Hafner \& Mayer-Foulkes, 2013).

Sasaran utama pembangunan adalah masyarakat, sedangkan pemerintah berperan sebagai fasilitator mencapai tujuan Pembangunan Nasional. Upaya pemberdayaan masyarakat melawan kemiskinan serta kesenjangan ekonomi antara kota dan desa menjadi agenda penting dalam kegiatan pembangunan di masa yang akan datang (Utami et al. 2018). Pemberdayaan haruslah melibatkan peran masyarakat yang lebih besar. Hal ini dapat dimulai dari merencanakan, melaksanakan, menerima hasilnya, merasakan manfaatnya, sehingga pada pemeliharaan hasil-hasil pembangunan tersebut (Blair, 2004; Dola \& Mijan, 2006; Li et al., 2012).

Sejak tahun 2007 pemerintah Indonesia mengimplementasikan kebijakan pemberdayaan masyarakat perdesaan melalui Program Nasional Pemberdayaan Masyarakat Mandiri Perdesaan (PNPM-MP). Program ini merupakan kelanjutan dari Program Pengembangan Kecamatan (PPK), yang selama ini dinilai berhasil. Hal ini terlihat dari adanya penyediaan tenaga kerja dan peningkatan pendapatan kelompok rakyat miskin, efisiensi dan efektifitas kegiatan, dan keberhasilan dalam menumbuhkan kolektifitas serta partisipasi masyarakat. tahapan pelembagaan sistem pembangunan partisipatif.

Kebijakan adalah rumusan dari alokasi nilai-nilai yang otoritatif saja untuk seluruh masyarakat dipilih oleh pemerintah untuk dikerjakan (Ogundiya, 2010; Arifani, 2021). Artinya pemerintah dalam upaya membuat formulasi kebijakanan publik beranjak dari pada Pembukaan Undang-Undang Dasar, Batang Tubuh Undang-Undang Dasar dan Undang-Undang, serta peraturan pemerintah yang mengikat yang dapat mempengaruhi ataupun merubah paradigma masyarakat, dari paradigma lama menuju paradigma baru (Thoha, 2017).

Lebih jauh lagi James E. Anderson mendefinisikan kebijakan sebagai suatu rangkaian tindakan pemecahan masalah untuk mencapai tujuan yang dikehendaki. Kebijakan publik itu mempunyai implikasi antara lain; (1) berorientasi pada tujuan; (2) pola-pola tindakan pejabat-pejabat pemerintah; (3) apa yang benar-benar dilakukan pemerintah, (4) bisa bersifat positif atau negatif. Hal ini berarti kebijakan publik itu jelaslah tidak hanya asal dibuat saja, dan dipublikasikan melainkan justru kebijakan publik itu harus mempunyai suatu tujuan yang pasti, dan kesiapan birokrasi pemerintah untuk mensosialisasikan program ataupun melaksanakan program, dan tersedianya sumber daya manusia serta terdapatnya suatu kekuatan program untuk memperbaiki dan/atau mempengaruhi masyarakat (Anderson, 2003).

Ada 5 (lima) elemen kebijakan publik yaitu: (1) tujuan, (2) terkait satu sama lain, (3) senyatanya dilakukan pemerintah, (4) bisa bersifat positif dan negatif, (5) otoritatif (Widodo, 2001). Artinya kebijakan publik (policy) yang dibuat terlebih dahulu dikaji berdasarkan sifat otoritatif dengan berorientasi kepada paradigma baru untuk pemecahan isu-isu yang krusial, dalam rangka membuat suatu kebijakan melalui berbagai rangkaian tahapan sebagaimana dinyatakan (Dunn, 2000), kebijakan adalah meliputi; (a) penyusunan agenda, (b) formulasi kebijakan, (c) adopsi kebijakan, (d) implementasi, dan (e) penelitian.

Lebih lanjut, guna mencapai tujuan kebijakan, pemerintah harus melakukan aksi atau tindakan yang berupa perhimpunan sumber daya dan pengelola sumber daya (Carmona-Torres et al., 2011). Hasil yang diperoleh dari aksi pertama dapat disebut sebagai proses implementasi kebijakan dan di dalam proses kebijakan terdapat tidak saja perilaku administratif dan organisasional melainkan juga perilaku politis. Implementasi 
kebijakan merupakan suatu proses untuk mewujudkan tujuan-tujuan yang telah dipilih dan ditetapkan menjadi kenyataan atau dengan kata lain penerapan perencanaan ke dalam praktek. Namun dalam hal ini tidak semua program yang diimplementasikan dapat berlangsung dengan mulus dan efektif.

Gejala ini menurut Gunn (1978) dinamakan sebagai implementasi gap, sebagai suatu keadaan dimana dalam proses kebijakan selalu terbuka kemungkinan terjadinya perbedaan apa yang diharapkan/direncanakan oleh pembuat kebijakan dengan apa senyatanya dicapai. Gagasan ini telah dilengkapi dalam beberapa tahun terakhir oleh pemikiran sistem yang kompleks yang diinformasikan oleh gagasan ketidakpastian, nonlinier, dan kemampuan beradaptasi (Braithwaite et al., 2018).

Satu pilar utama dalam implementasi kebijakan publik adalah menetapkan organisasi pelaksana, baik tentang sumber daya, unit serta metode yang dijadikan kebijakan tersebut dilaksanakan (Mursalim, 2017), Melalui keberadaan organisasi pelaksana, proses implementasi kebijakan secara fungsional akan jelas pihak penanggung jawabnya, tercipta ketertiban alokasi sumber daya yang diperlukan baik personil, dana, perlengkapan, metode dan prosedur baku yang berlaku Jika kita tinjau dari implementasi Program Nasional Pemberdayaan Masyarakat Mandiri Bidang Infrastruktur Perdesaan Tahun 2009, maka sangatlah tepat jika pendekatan yang tepat adalah pendekatan gabungan antara kebijakan yang berpola "dari atas ke bawah" (top-bottomer) versus "dari bawah ke atas" (bottom-topper). Ada tiga unsur penting dalam proses implementasi, yaitu: (i) adanya program kebijakan yang dilaksanakan (ii) target group, yaitu kelompok masyarakat yang menjadi sasaran dan diharapkan akan menerima manfaat dari program, perubahan atau peningkatan (iii) Unsur pelaksana (implementor) baik organisasi baik perorangan untuk bertanggungjawab dalam memperoleh pelaksanaan dan pengawasan dari proses implementasi tersebut. Adapun unsur pelaksanan atau implementor yang bertanggungjawab terhadap keberhasilan program adalah aparat birokrasi pemerintah secara berjenjang mulai dari aparat birokrasi pada tingkat Desa/Lurah, Kecamatan, Kabupaten/Kota, Provinsi hingga tingkat Nasional.

Sebagai acuan untuk mengetahui kendala ataupun pendorong yang menyebabkan sesuai tidaknya implementasi PNPM Mandiri Perdesaan di lapangan (das sein) dengan dikehendaki (das sollen) berikut dikemukakan beberapa aspek penting berdasarkan pendapat George C. Edwars III yaitu 1). Komunikasi, 2). Sumberdaya, 3). Sikap, serta diramu dengan pendapat George S. Blair yaitu 4). Kondisi sosiao-ekonomis dan lingkungan fisik (geografis). 5). Kondisi demografis.

Pertama, aspek komunikasi (communication) komukasi yang akurat akan mendukung keleluasaan implementor kebijakan penjabaran kebijakan umum kedalam tindakan-tindakan operasional tertentu. Komunikasi ini berhubungan dengan aspek-aspek pengiriman pesan (transmission), kejelasan informasi (clarity), dan konsistensi terhadap penyampaian pesan/informasi (consistency) tersebut. Bila mana salah satu atau bahkan keseluruhan aspek ini tidak ditangani dengan benar, maka akan terjadi kendala komunikasi dalam implementasi kebijakan. Untuk itu suatu kebijakan harus disampaikan dengan benar, jelas dan konsisten. Namun kejelasan informasi itu tidak berarti informasi harus terinci sehingga mematikan kreativitas dan adaptasi implementor di lapangan (Edward III, 1978).

Kedua, Sumberdaya (resource). Sumber daya tidak hanya berkenaan dengan sumber daya manusia (staff), tetapi juga meliputi informasi (information), otoritas (authority) dan fasilitas (facilities) yang tersedia. Sudah barang tentu sumber daya manusia memegang peran penting dalam rangka mengimplementasikan suatu kebijakan. Dalam hal ini dibutuhkan adalah kuantitas yang memadai dan sekaligus kualitas yang dikehendaki untuk melaksanakan kebijakan yang telah dicetuskan. Untuk itu diperlukan pula adanya informasi yang relevan atau akurat baik tentang bagaimana kebijakan itu harus diimplementasikan maupun aspekaspek lain yang terlibat didalamnya, otoritas dalam rangka mengimplementasikannya dan 
fasilitas pendukungnya. Bila mana aspek sumber daya itu tidak diperhitungkan dengan sungguh-sungguh, maka aspek ini pun akan menjadi kendala bagi keberhasilan implementasi kebijakan (Edward III, 1978).

Ketiga, sikap (dispositions) sikap tindakan-tindakannya meliputi tiga aspek yang saling terkait, yaitu efek sikap (effects of dispositions), staf birokrasi (staffing the bureaucracy), dan insentif (incentives). Pada dasarnya sikap sikap-sikap seseorang implementor sangat dipengaruhi pula oleh pandangan mengenai esensi suatu kebijakan dan pengaruh kebijakan terhadap organisasi dan kepentingan anggota-anggotanya. Sehubungan dengan itu, suatu kebijakan yang dirumuskan hendaknya dimanipulasi sedemikian rupa sehingga sesuai dengan lingkungan kerja implementor dan sekaligus sejauh mungkin meredusir keleluasaannya untuk tidak menyimpang dari peraturan yang ada dan keluaran kebijakan yang ingin dicapai (Edward III, 1978). Keempat, aspek kondisi sosio-ekonomis dan lingkungan fisik (geografis). Para pakar umumnya sependapat bahwa keragaman kondisi antar daerah diindikasikan oleh keragaman kondisi sosioekonomi, namun pendapatnya bervariasi mengenai aspek lain. Kelima, kondisi demografis yang meliputi jenis penduduk, usia, pekerjaan dan komposisinya. Aspek yang paling berpengaruh adalah jenis pekerja.

Kajian mengenai implementasi kebijakan dalam pembangunan infrastruktur jalan di daerah pedalaman masih jarang dilakukan. Salah satu kajian tersebut mengupas tentang implementasi pembangunan infrastruktur jalan dengan model Donald Van Metter dan Carl Van Horn (Kurniawan \& Maani, 2020). Dari uraian sebelumnya, jelaslah tergambar bahwa implementasi kebijakan berkaitan dengan aktivitas dan atau tindakan-tindakan yang dilakukan pemerintah maupun masyarakat maupun sektor-sektor publik tertentu. Tujuan penelitian ini adalah untuk memaparkan implementasi pembangunan jalan pada daerah pinggiran di Desa Ensaid Panjang, Kecamatan Kelam Permai, Kabupaten Sintang.

\section{METODE PENELITIAN}

Penelitian ini merupakan jenis penelitian deskriptif kualitatif. Hal ini berhubungan dengan tujuan dari metode ini yakni untuk menginterpretasi perilaku manusia yang bermakna, baik tentang diri mereka sendiri maupun orang lain. Sejalan dengan pengetian tersebut Nawawi (2003) mengemukakan "metode deskriptif dapat diartikan sebagai prosedur pemecahan masalah yang diselidiki dengan menggambarkan/melukiskan keadaan subyek/obyek penelitian (seorang, lembaga, masyarakat dan lain-lain) pada saat sekarang berdasarkan fakta-fakta yang tampak atau sebagaimana adanya". Subjek penelitian ini adalah: Kepala Desa Ensaid Panjang, Pengelola/Fasilitator PNPM-MP bidang Prasarana Jalan, Ketua Tim Pelaksana Kegiatan (TPK), Ketua LKD, Tiga orang anggota masyarakat Desa Ensaid Panjang

Sehubungan dengan hal tersebut, guna memperoleh data yang akurat dan berkualitas, digunakan teknik pengumpulan data yaitu Observasi, Wawancara, dan Studi dokumentasi. Alat yang digunakan yaitu Panduan Observasi, Panduan Wawancara (interview guide) dan Alat Dokumentasi. Lokasi penelitian adalah di Desa Ensaid Panjang Kecamatan Kelam Permai Kabupaten Sintang.

Data yang telah diperoleh dianalisis dengan menggunakan analisis data kualitatif (Miles et al., 2014). Pendekatan triangulasi diterapkan untuk mengekstrak data berdasarkan konsistensi informasi satu sama lain dan berdasarkan observasi. Pengamatan dilakukan terhadap aktivitas pekerjaan kontruksi dan pascakontruksi.

\section{HASIL DAN PEMBAHASAN \\ Perencanaan Kegiatan Prasarana}

Perencanaan kegiatan pembangunan desa dilakukan melalui musyawarah. Musyawarah dilakukan dalam lembaga di tingkat desa yaitu Lembaga Kemasyarakatan Desa (LKD). Kegiatan ini dilakukan sebelum pembangunan dilaksanakan agar pembangunan dapat berjalan lancar. Lembaga ini membicarakan dan mempertimbangkan kondisi lingkungan sekitar karena berhubungan dengan ijin yang harus didapatkan dari para pemilik tanah di sekitar 
area yang akan dipakai untuk pembangunan prasarana. Para pemilik tanah di sekitar area pembangunan dikumpulkan dan dijelaskan mengenai sejauh mana pembangunan prasarana jalan tersebut akan mempengaruhi tanah mereka. Bentuk partisipasi masyarakat dalam perencanaan telah berjalan sesuai dengan aturan yang tercantum dalam pedoman pelaksana PNPM Mandiri Perdesaan. Perencanaan partisipasip telah dilakukan dalam bentuk musyarawarah melalui beberapa tahap:

\section{Musyawarah Desa I}

Dalam Musyawarah Desa I yaitu membentuk Lembaga Kemasyarakatan Desa (LKD) dan penetapan Kader Desa (KD). Pembentukan Lembaga Kemasyarakatan Desa (LKD) difasilitasi oleh Fasilitasor Kecamatan.

Pada Musyawarah Desa I, yaitu dalam menetapkan Kader Desa dan Lembaga Kemasyarakatan Desa (LKD) pada awalnya terdapat perdebatan di antara peserta musyawarah, hal ini terjadi karena di desa tersebut terdapat beberapa dusun yang berbeda. Atas dasar itulah mereka lebih mengutamakan orang-orang yang ada didusunnya, namun berkat dibantu atau difasilitasi oleh Tim Pelaksana Kabupaten, Tim kecamatan, Fasilitator Manajemen Kabupaten (FMK), Fasilitator Kecamatan (FK), dan Tim dari desa maka Musyawarah Desa I dapat berjalan dengan lancar dan normal, rata-rata keputusan diambil dengan cara musyawarah mufakat/aklamasi.

Musyawarah Desa I dapat berjalan dengan baik karena Fasilitator Kecamatan berperan aktif dalam mengatasi perbedaan pendapat dalam musywarah dimaksud dan Fasilitator Kecamatan menekankan pada setiap musyawarah ini agar masyarakat desa mengesampingkan kepentingan-kepentingan pribadi atau kelompok dan mengutamakan kepentingan masyrakat secara keseluruhan.

\section{Musyawarah Desa II}

Dalam Musyawarah Desa II yaitu kegiatan LKD dalam mengidentifikasi permasalahan infrastruktur di desanya serta menetapkan usulan kegiatan berdasarkan skala prioritas. Usulan kegiatan yang telah disepakati bersama selanjutnya ditetapkan sebagai usulan Lembaga Kemasyarakatan Desa
(LKD) serta ditindaklanjuti dengan membuat Usulan dan Rencana Anggaran Biaya (RAB).

\section{Musyawarah Desa III}

Dalam Musyawarah Desa III yaitu kegiatan LKD yang bertujuan untuk menetapkan rencana pelaksanaan pembangunan infrastruktur, membentuk Kelompok Pemanfaatan Pemelihara (KPP), menetapkan rencana operasi dan pemeliharaan serta rencana pendanaannya, dan pencadangan dana pemeliharaan.

\section{Pelaksanaan Kegiatan Konstruksi Prasarana}

Kegiatan kontruksi yang dilaksanakan melalui PNPM Mandiri adalah jalan alteri berbatu sepanjang 3500 meter. Proses pelaksanaan kegiatan konstruksi prasarana jalan meliputi beberapa kegiatan yang terkait di dalamnya, seperti persiapan, pelaksanaan fisik di lapangan, pengadaan material, pengadaan alat dan pengendalian tenaga kerja, serta pengendalian pengeluaran dana. Tim Pelaksana Kegiatan (TPK) melaksanakan kegiatan yang terkait di dalamnya secara bersamaan sesuai dengan kebutuhan di lapangan yang dituangkan dalam bentuk jadwal pelaksanaan, jadwal pengadaan material, kebutuhan alat dan tenaga kerja. Ketua TPK bertanggung jawab atas kelancaran jalannya kegiatan konstruksi, dibantu oleh satu atau beberapa orang mandor. Pekerjaan persiapan pelaksanaan dapat dilakukan secara simultan dengan pengajuan anggaran dan pencairan dana setelah penetapan dana dalam Musyawarah Penetapan Usulan. Pekerjaan ini dilakukan oleh TPK dibantu Fasilitator Kecamatan.

Dalam pelaksanaan kegiatan prasarana jalan di Ensaid Panjang ini masyarakat, melalui TPK, memang terlibat terutama dalam hal penyusunan jadwal kegiatan dan pembagian kerja tetapi berhubungan dengan pelatihan teknis masih belum ada dibicarakan. Sebagai akibatnya pembekalan teknis kepada masyarakat pekerja pun sangat minim. Masyarakat bekerja sesuai dengan kemampuan yang ada pada mereka tanpa adanya peningkatan kompetensi kerja yang berarti. Menurut informan yang berasal dari unsur pekerja, 
"Tenaga kerja terdiri dari pekerja biasa, tukang yang mempunyai suatu keterampilan yang dibutuhkan seperti tukang batu atau tukang kayu, dan kepala kelompok. Satu kelompok biasanya terdiri dari 20 pekerja biasa dan satu kepala kelompok. Insentif harian untuk kepala kelompok ditetapkan sedikit di atas insentif tukang. Sedangkan insentif seorang pekerja biasa lebih kecil dari insentif tukang. Insentif harian untuk kepala kelompok ditetapkan sedikit di atas insentif tukang. Upah para pekerja (tukang) sebesar Rp. 40.000,- (empat puluh ribu rupiah) per hari untuk dan Rp.60.000,- (enam puluh ribu rupiah) untuk tukang kepala."

Informan yang berasal dari unsur fasilitator menambahkan informasi sebagai berikut:

"Insentif PNPM Mandiri Perdesaan merupakan perangsang (bukan upah) yang dihitung berdasarkan satu HariOrang-Kerja minimal selama 6 jam. Jika seseorang harus bekerja sekian jam (lebih dari 6 jam), maka dapat dibayar lebih banyak dalam satu hari sesuai dengan perbandingan jam minimal HOK."

Pelaksanaan kegiatan konstruksi di lapangan dilaksanakan oleh masyarakat sendiri yang dipimpin oleh Ketua TPK Fasilitator Teknis di tingkat Kecamatan mempunyai tanggung jawab untuk memfasilitasi bagaimana hal ini dapat dilaksanakan dengan baik oleh masyarakat. Ketua TPK Fasilitator Teknis menyampaikan informasi sebagi berikut,

"Harus diciptakan suasana serta tujuan untuk membangun desa sendiri yang berbeda dengan bekerja pada proyek komersial. Kegiatan pelaksanaan konstruksi di lapangan harus didasari dengan azas Dari, Oleh, dan Untuk Masyarakat, sehingga ada rasa memiliki terhadap kegiatan konstruksi di lapangan."

Untuk mengendalikan kualitas pelaksanaan, kualitas prasarana yang dibangun perlu ditinjau secara berkala. Hasil peninjauan ini dapat dituangkan oleh FT-Kec pada sebuah formulir pemeriksaan, untuk selanjutnya dianalisis oleh FT-Kab. Hasil tersebut berfungsi pula sebagai alat penyuluhan kepada masyarakat desa, mandor, dan PJOK, supaya kualitas prasarana yang dibangun dapat ditingkatkan.

Ketua TPK Fasilitator Teknis menyampaikan juga menyampaikan informasi terkait dengan kendala sebagai berikut,

"Selama pelaksanaan kegiatan pembangunan prasarana jalan ini juga mengalami kendala teknis. Hal ini terjadi pada saat pengerjaan sekitar dua ratus meter penimbunan jalan. Pada perhitungan semula diperkirakan kayu cerucuk yang diperlikan sekitar 190 buah. Ternyata dalam pelaksanaan dibutuhkan sekitar 2.300 buah kayu cerucuk. Hal ini merupakan salah satu hambatan dalam mengejar batas waktu yang ditentukan, yakni sekitar 90 hari kerja."

\section{Pemeliharaan Hasil Pembangunan}

Pasca penyelesaian kegiatan merupakan tahap pasca pelaksanaan pembangunan yang wajib dioperasikan dan dipelihara oleh desa. Agar kegiatan pembangunan prasarana, mempunyai nilai manfaat yang dapat terus berlangsung dan berkembang. Kesanggupan desa untuk memelihara hasil kegiatan tersebut sudah termasuk pada kriteria pengajuan usulan desa pada musyawarah desa (merupakan bagian yang tidak terpisahkan dari usulan desa).

Tim Pengelola Pemeliharaan Prasarana (TP3) pembanguan berasal dari tiga dusun yang ada. Tim ini terdiri dari 5 orang berasal dari tiga dusun yang ada di Desa Ensaid Panjang, yang bertugas mejaga kelestarian dari hasil pembangunan ini. Namun sampai saat ini tim ini kurang berfungsi karena sejak prasarana selesai dikerjakan, pihak pemerintah tidak lagi ada perhatian terutama dalam hal pemeliharaan prasarana jalan yang telah dibangun. Tim yang ada sudah mengajukan ke Kecamatan mengenai perkiraan biaya untuk pemeliharaan prasarana jalan tersebut namun belum ada realisasi kucuran dana.

Semua tahapan pemeliharaan telah dilakukan sesuai dengan prosedur yang terdapat dalam program PNPM Mandiri Perdesaan. Tim Pemelihara telah berusaha mengidentifikasi permasalahan yang ada di 
lapangan dan telah diadakan usulan ke kecamatan berkenaan dengan apa yang memang perlu diperbaiki, termasuk kebutuhan akan besarnya biaya. Pemeliharaan hasil pembangunan sebenarnya membutuhkan kerja sama antara masyarakat dan pihak Pemerintah Daerah, dalam hal ini Kecamatan Kelam Permai. Pekerjaan pemeliharaan prasarana tidak akan bisa diatasi hanya oleh masyarakat. Ketika diwawancara, ketua Tim Pelaksana Kegiatan (TPK), menyampaikan:

"Warga masyarakat telah
melakukan langkah-langkah yang
diperlukan agar kondisi jalan tetap bisa
tepelihara. Langkah tersebut antara lain
dengan mengadakan kerja bakti untuk
membersihkan rumput-rumput agar
tidak tumbuh dan menimbun tempat
tertentu yang mulai berlobang. Lobang-
lobang yang ada ditimbun dengan batu
dan dikerjakan secara manual."

Dari fakta-fakta yang terjadi di lapangan penulis berkesimpulan bahwa memang telah terbentuk Tim Pengelola Pemeliharaan Prasarana (TP3), namun mereka tidak bisa berbuat banyak karena belum ada dana yang tersedia, terutama dari pemerintah. Sehingga, bisa dipastikan prasarana jalan yang sudah dibangun akan terbengkalai karena tidak adanya rencana pembangunan yang berkesinambungan. Langkah-langkah yang diambil oleh tim sementara adalah mengajak masyarakat untuk bersama-sama dalam bentuk kerja bakti.

\section{Kesadaran Masyarakat}

Dari hasil penelitian di lapangan ternyata kesadaran masyarakat untuk mendukung implementasi Program Nasional Pemberdayaan Masyarakat Mandiri Perdesaan bidang prasarana jalan di Desa Ensaid Panjang cukup tinggi. Hal ini didukung oleh kenyataan di lapangan bahwa masyarakat Desa Ensaid Panjang merupakan sebuah desa yang memiliki budaya gotong royong. Salah satu faktor pelestari budaya gotong royong adalah adanya rumah betang yang sampai sekarang kondisinya masih asli dan dihuni oleh sekitar 28 keluarga.

Selain itu, partisipasi masyarakat dalam perencanaan, pelaksanaan sampai terbentuknya Tim Pengelola Pemelihara Prasarana (TP3) pembangunan juga sangat baik. Pemerintah desa telah berupaya menggerakkan swadaya masyarakat sehingga terkumpul dana partisipasi dari masyarakat Rp. 6.000.000,- (enam juta rupiah). Namun demikian, setelah pembangunan diselesaikan, tidak ada upaya dari pemertintah desa untuk menggerakkan swadaya masyarakat. Yang terjadi adalah masyarakat tetap menunggu kucuran dana dari pemerintah kecamatan yang tidak kunjung ada meskipun proposal telah dibuat oleh Tim Pengelola Pemeliharaan Prasarana (TP3) pembanguan. Sebenarnya perlu adanya upaya pemerintah desa untuk menggerakkan swadaya masyarakat, bukan hanya menunggu kucuran dana dari Pemerintah Kecamatan dan Kabupaten.

Dari hasil wawancara dengan salah satu warga. Informat tersebut menyatakan informasi sebagai berikut:

"Kesadaran masyarakat Desa Ensaid Panjang dalam menerima Program Nasional Pemberdayaan Masyarakat Mandiri Perdesaan bidang prasarana jalan sangat tinggi. Masyarakat di sini menyadari betul pentingnya jalan sebagai akses keluar agar lokasi desa mereka tidak terisolasi. Bagi mereka akses jalan tersebut merupakan suatu kebutuhan yang telah diimpikan sejak lama. Di samping itu masyarakat merasa sangat dihagai karena mereka boleh dilibatkan dalam setiap tahap perencanaan pembangunan prasarana jalan ini. Selain karena pemahaman tersebut, mereka adalah masyarakat yang menjunjung tinggi budaya gotong royong. Itulah sebabnya tidak sulit bagi masyarakat untuk mau terlibat dalam setiap kegiatan yang dilaksanakan dalam pembangunan."

Kepala Desa Ensaid panjang mengungkapkan bahwa pengaruh kesadaran masyarakat Ensaid Panjang terhadap implementasi Program Nasional Pemberdayaan Masyarakat Mandiri Perdesaan bidang prasarana jalan sangat besar. Meskipun dalam pelaksanaan pembangunan prasarana jalan masih mengalami sedikit hambatan. Hal 
ini dihngkapkan oleh kepala Desa yang menyatakan informasi sebagai berikut:

"Dalam pelaksanaan pembangunan prasarana jalan masih mengalami sedikit hambatan terutama dalam penimbunan jalan sekitar 200 meter dimana telah terjadi kesalahan teknik dalam perhitungan dan juga pengaruh cuaca yang kurang mendukung (musim hujan), berkat dukungan masyarakat yang begitu besar dalam bentuk gotong royong akhirnya pembangunan prasarana jalan ini bisa diselesaikan dengan baik."

Sikap positif masyarakat juga diakui oleh informan dari unsur Fasilitator Kecamatan. Informan tersebut menyampaikan informasi sebagai berikut:

"Selama proses Implementasi Program Nasional Pemberdayaan Masyarakat Mandiri Perdesaan bidang prasarana jalan, mulai dari sosialisasi, perencanaan, sampai pada pelaksanaan kegiatan, masyarakat terlibat dengan sangat antusias. Bahkan dalam hal pemeliharaan pun telah dibentuk Tim Pengelola Pemeliharaan Prasarana (TP3) yang beranggotakan lima orang dan berasal dari tiga dusun yang ada di Desa Ensaid Panjang. Meskipun akhirnya tim ini belum bisa berbuat banyak karena belum adanya anggaran yang diberikan oleh pemerintah untuk pemeliharaan prasarana yang telah dibangun."

Berdasarkan pengakuan dari beberapa subyek penelitian tersebut maka peneliti berpendapat bahwa dukungan dan kesadaran masyarakat terhadap implementasi Program Nasional Pemberdayaan Masyarakat Mandiri Perdesaan bidang prasarana jalan di Desa Ensaid Panjang sangat tinggi. Alasan tingginya kesadaran masyarakat karena beberapa hal, seperti adanya azas manfaat bagi kelompok sasaran atau penerima program dan tentunnya juga karena karakter masyarakat Desa Ensaid Panjang itu sendiri yang sampai saat ini masih memegang erat budaya kerja sama atau gotong royong. Hal tersebut sangat berpengaru terhadap implementasi PNPM Mandiri
Perdesaan Bidang Prasarana Jalan di desa ini. Sikap positif masyarakat terhadap program ini terlihat dari bentuk swadaya masyarakat berupa keterlibatan mereka dalam menyumbangkan anggaran sebesar Rp. 6.000.000,- (enam juta rupiah) dari total anggaran Rp. 266.000.000,- (dua ratus enam puluh enam juta rupiah), aktif sebagai pekerja dengan upah di bawah standar setempat dan berbagai kegiatan gotong royong.

\section{Organisasi Pelaksana}

Organisasi pelaksana pada implementasi Program Nasional Pemberdayaan Masyarakat Mandiri Perdesaan bidang prasarana jalan di Desa Ensaid Panjang bersala dari Tim Kabupaten, Kecamatan, dan Desa. Namun yang paling berperan adalah Fasilitator Kecamatan (FK), Fasilitator Teknik kecamatan (FT-kec) dan Tim Pelaksana Kegiatatan (TPK) di tingkat desa. Selain fasilitaor Tim Pelaksana Kegiatatan juga berasal dari anggota masyarakat yang dipilih melalui musyawarah desa yang secara umum mempunyai fungsi dan peran untuk mengelola dan melaksanakan PNPM Mandiri Perdesaan. Dalam pelaksanaan kegiatan PNPM-MP Prasarana Jalan di Desa Ensaid Panjang, menurut hasil wawancara dengan Ketua TPK, Tim Pelaksana Kegiatan terdiri dari Ketua, Sekretaris, dan Bendahara.

Menurut Kepala Desa Ensaid Panjang, kemampuan organisasi pelaksana tingkat desa sudah cukup memadai baik dari jumlah personal maupun kualitasnya.

"Keberadaan organisasi pelaksana kebijakan Program Nasional Pemberdayaan Masyarakat Mandiri Perdesaan bidang prasarana jalan selain untuk memenuhi persyaratan formal sesuai dengan Pedoman Umum dan Pedoman Pelaksanaan Program Nasional Pemberdayaan Masyarakat Mandiri Perdesaan bidang prasarana jalan, juga untuk memberikan kejelasan kepada masyarakat yang desanya menjadi sasaran kebijakan Program Nasional Pemberdayaan Masyarakat Mandiri Perdesaan bidang prasaran."

Dengan demikian pada saat masyarakat hendak melaksanakan program tersebut, 
mereka dapat mengetahui organisasi pelaksana mana yang akan mereka hubungi.

Menurut pendapat Ketua Lembaga Kemasyarakatan Desa (LKD) Ensaid Panjang peran Fasilitator Kecamatan sangat besar. Informan yang berasal dari unsur LKD menyampaikan bahwa

"Fasilitator dan pelaksana teknis telah berperan sebagai penggerak dan pengendali dari seluruh kegiatan implementasi PNPM Mandiri Perdesaan di Desa Ensaid Panjang. Sebagai perwakilan dari pemerintah fasilitator telah berusaha semanksimal mungkin untuk mensukseskan kegiatan PNPM ini. Dari sekian banyak tugas dan tanggung jawab fasilitator kecamatan yang ditetapkan, hanya pelatihan yang kurang banyak dilakukan. Hal ini bisa dimaklumi karena pelatihan teknis merupakan tanggung jawab Fasilitator Teknik Kecamatan (FT-Kec)."

Masalah teknis adalah masalah serius yang harus dikuasai oleh para perkerja konstruksi prasarana jalan. Oleh karena itu peran dari Fasilitator Teknik Kecamatan dalam memberikan pelatihan teknis kepada para pekerjasangatlah penting. Organisasi pelaksana ini sangat diharapkan oleh masyarakat yang akan mampu memberikan bekal teknis kepada mereka bukan saja berguna pada saat pelaksanaan PNPM tetapi juga berguna pasca pelaksanaan manakala mereka mendapatkan pekerjaan serupa pda kesempatan lain. Di sinilah kemandirian yang sesungguhnya. Menurut salah seorang masyarakat pekerja PNPM-MP, tidak banyak kemampuan teknik yang mereka dapatkan karena tidak adanya pelatihan teknik khusus diberikan oleh Fasilitator Teknik Kecamatan. Salah satu informan dari unsur masyarakat pekerja, menyampaikan informasi sebagai berikut:

"Fasilitator teknis memang jarang berada di lapangan. Bahkan dikabarkan petugas tersbut sudah pindah kerja ke tempat lain sebelum kegiatan PNPM selesai. Itulah sebabnya banyak pihak yang kurang paham mengenai permasalah ini termasuk Kepala Desa sekalipun."
Ketidak jelasan keterlibatan Fasilitator Teknik Kecamatan merupakan salah satu hambatan yang di temui di lapangan. Itulah sebabnya kesalahan teknik perhitungan kebutuhan cerucuk menjadi masalah besar bagi para pekerja dan sebagian besar masyarakat mengkritisi permasalah tersbut.

Dalam hal upaya pengembangan SDM pelaksana menurut Kepala Desa Ensaid Panjang hal ini belum memadai. Kepala Desa Ensaid menyatakan bahwa:

"Belum ada pelatihan teknik secara khusus dan berkesinambungan yang diberikan oleh Fasilitator Teknik Kecamatan kepada organisasi pelaksana di tingkat desa. Kemampuan administratif mungkin sudah cukup baik tetapi kemampuan teknik pekerja masih sangat kurang. Hal ini mengakibatkan mereka belum siap pakai apabila ada proyek-proyek konstruksi jalan yang dilakukan di daerah lain."

Dengan demikian dapat disimpulkan bahwa kemampuan organisasi pelaksana PNPM Mandiri Perdesaan Bidang Prasarana Jalan di Desa Ensaid Panjang Bidang Prasarana Jalan di Desa Ensaid Panjang Kecamatan Kelam Permai tingkat desa cukup baik meskipun belaum ada upaya yang berarti dalam peningkatan kualitas SDM. Di tingkat kecamatan organisasi pelaksana yang bertanggung jawab adalah Failitator Kecamatan dan Fasilitator Teknik Kecamatan. Kemampuan kedua organisasi pelaksana dari kecamatan cukup baik meskipun disayangkan bahwa keterlibatan FT-Kec belum bisa maksimal.

\section{Anggaran}

Kepala Desa Ensaid Panjang mengatakan bahwa anggaran yang disediakan oleh pemerintah lewat Program Nasional Pemberdayaan Masyarakat Mandiri Perdesaan bidang prasarana jalan di Desa Ensaid Panjang ditetapkan oleh pemerintah. Jadi besarnya anggaran yang ditetapkan tersebut dituangkan dalam Keputusan Camat yang selanjutnya akan mempengaruhi semua perencanaan yang akan disusun oleh para pelaku PNPM Mandiri Perdesaan Bidang Prasarana. Lebih lanjut dia Kepala Desa mengatakan bahwa: 
"Rencana anggaran yang sudah ditetapkan melalui Surat Penetapan Camat sangat besar pengaruhnya terhadap semua proses kegiatan pembangunan melalui Program Nasional Pemberdayaan Masyarakat Mandiri Perdesaan di Desa Ensaid Panjang. Bahkan besarnya anggaran yang ditetapkan mempengaruhi semua tahapan proses implementasi program yang dijalankan. Namun yang menyolok adalah pengaruh perencanaan anggaran terhadap upah para pekerja relatif kecil serta tidak adanya pelatihan kemampuan teknik khusus sehingga bisa membekali untuk bekerja dalam bidang pekerjaan yang sama. Anggaran yang ada tidak bisa membantu meningkatan SDM secara optimal".

Dari hasil wawancara dengan Ketua Tim Pelaksana Kegiatan (TKP) Desa Ensaid Panjang terungkap bahwa semula panjang prasarana jalan yang akan dikerjakan adalah 3.500 meter (sesuai Surat Petetapan Camat Nomor 4 tahun 2011) tetapi karena keterbatasan dana yang disediakan pemerintah, proyek ini hanya bisa dikerjakan sepanjang 3.000 meter.

"Sumber dana Program Nasional Pemberdayaan Masyarakat Mandiri Perdesaan Bidang Prasarana jalan di Desa Ensaid Panjang tahun 2012 berasal dari APBN Tahun anggaran 2011 didukung dengan dana operasional yang berasal dari APBD Kabupaten Sintang. Total dana dari pemerintah berdasarkan Surat Penetapan Camat Kelam Permai adalah sebesar Rp. 266.000.000,- (Dua ratus enam puluh enam juta rupiah) dan dana dari swadaya masyarakat sebesar Rp.6.000.000,- (enam juta rupiah)."

Ketika diwawancara mengenai kecukupan dana yang tersedia, salah seorang warga masyarakat dari Ensaid Panjang mengatakan bahwa:

"Dana yang disediakan untuk mengerjakan Program Nasional Pemberdayaan Masyarakat Mandiri Perdesaan bidang prasarana jalan di Ensaid Panjang ini belum mencukupi. Buktinya ada pengurangan panjang jalan yang semula saya dengar 3.500 meter menjadi 3.000 meter. Masyarakat senang bisa dilibatkan dalam perencanaan pembangunan ini dan bersyukur karena bisa menikmati hasil pembangunannya. Namun masyarakat juga sangat berharap adanya peningkatan mutu SDM yang optimal terutama yang berhubungan dengan kemampuan teknis sehingga dampak dari PNPM Mandiri Perdesaan ini masih bisa dirasakan meskipun kegiatan ini telah berakhir. Itu semua tidak dimungkinkan karena dana yang terbatas."

Berdasarkan pendapat beberapa subjek penelitaian tersebut penulis berpendapat bahwa anggaran yang disediakan oleh pemerintah dan yang berasal dari swadaya masyarakat belumlah mencukupi, meskipun secara umum pelaksanaan Program Nasional Pemberdayaan Masyarakat Mandiri Perdesaan di Ensaid Panjang ini bisa berjalan dengan baik. Anggaran yang telah ditetapkan berpengaruh kepada seluruh tahapan proses implementasi Program Nasional Pemberdayaan Masyarakat Mandiri Perdesaan, mulai dari sosialisai, perencanaan, pelaksanaan, sampai pada tahap pemeliharaan.

Dalam pelaksanaan fisik prasarana masih terdapat kelemahan seperti perencanaan yang kurang memperhatikan faktor cuaca, anggaran yang kurang memadai sehingga tidak bisa dilaksanakan pelatihan teknis dan tidak tersediannya anggaran untuk pemeliharaan. Dalam penelitian sebelumnya dilaporkan bahwa faktor pendukung meliputi Kebebasan Terhadap Masyarakat, Dukungan Masyarakat Terhadap Kebijakan Pemerintah, Distribusi Dukungan Finansial dan Hubungan yang baik antar organisasi juga merupakan penentu suksesnya pelaksanaan. Adapun yang menjadi faktor penghambat meliputi sempitnya akses ke lokasi pelaksanaan dan sistem kerja oleh proyek (Mustafa, 2017).

\section{SIMPULAN}

Implementasi Program Nasional Pemberdayaan Masyarakat Mandiri Perdesaan Bidang Prasarana Jalan di Desa Ensaid Panjang Kecamatan Kelam Kabupaten Sintang secara 
umum telah berjalan cukup baik. Semua tahapan implementasi telah dilakukan sesuai prosedur yang tertuang dalam Petunjuk Teknis Operasional PNPM Mandiri Perdesaan.

Kesadaran masyarakat Desa Ensaid Panjang dalam kegiatan PNPM Mandiri Perdesaan Prasarana jalan sangat tinggi, terbukti dari antusiasnya masyarakat dalam berpartisipasi pada setiap tahapan proses pelaksanaan kegiatan. Namun demikian dukungan masyarakat ini belum diimbangi dengan kemampuan manajerial dan teknis yang memadai. Dalam pelaksanaan fisik prasarana masih terdapat kelemahan seperti perencanaan yang kurang memperhatikan faktor cuaca, anggaran yang kurang memadai sehingga tidak bisa dilaksanakan pelatihan teknis dan tidak tersediannya anggaran untuk pemeliharaan.

\section{DAFTAR PUSTAKA}

Blair, R. (2004). Public participation and community development: The role of strategic planning. Public Administration Quarterly, 28(1/2), 102-147.

Braithwaite, J., Churruca, K., Long, J. C., Ellis, L. A., \& Herkes, J. (2018). When Complexity Science Meets Implementation Science: A Theoretical and Empirical Analysis of Systems Change. BMC Medicine, 16(63). https://doi.org/10.1186/s12916-018-1057$\mathrm{z}$

Carmona-Torres, C., Parra-López, C., Groot, J. C. J., \& Rossing, W. A. H. (2011). Collective action for multi-scale environmental management: Achieving landscape policy objectives through cooperation of local resource managers. Landscape and Urban Planning, 103(1), 24-33.

Dola, K., \& Mijan, D. (2006). Public participation in planning for sustainable Development: Operational questions and issues. ALAM CIPTA, International. Journal of Sustainable Tropical Design Research and Practice, 1(1).

Dunn, W. N. (2000). Pengantar Analisis Kebijakan Publik. Gadjah Mada University Press.

Edward III, G. C. (1978). Understanding Public Policy. Prantice Hall.

Ferezagia, D. V. (2018). Analisis tingkat kemiskinan di Indonesia. Jurnal Sosial Humaniora Terapan, 1(1).

Gunn, L. A. (1978). Why is Implantation so Difficult? Management Services in Government, 33, 169-176.

Kurniawan, W., \& Maani, K. D. (2020). Implementasi kebijakan pembangunan infrastruktur jalan di Kecamatan Tabir Selatan Kabupaten Merangin dengan menggunakan Model Donald Van Metter dan Carl Van Horn. Jurnal Mahasiwa Ilmu Administrasi Publik ( JMIAP ), 2(2), 70-79.

Li, T. H. Y., Thomas Ng, S., \& Skitmore, M. (2012). Public participation in infrastructure and construction projects in China: From an EIAbased to a whole-cycle process. Habitat International, 36(1), 47-56. https://doi.org/https://doi.org/10.1016/j.h abitatint.2011.05.006

Miles, M. B., Huberman, A. M., \& Saldana, J. (2014). Qualitative Data Analysis: A Methods Sourcebook. (Edition 3). Sage Publication, Inc.

Mursalim, S. W. (2017). Implementasi Kebijakan Smart City di Kota Bandung. Jurnal Ilmu Administrasi, 14(1), 126-138.

Mustafa, C. S. (2017). Implementasi Pembangunan Infrastruktur Jalan Desa. JISIP : Jurnal IImu Sosial Dan Ilmu Politik, 6(3), 72. www.publikasi.unitri.ac.id

Thoha, M. (2017). Ilmu administrasi publik kontemporer. Penerbit Kencana.

Widodo, J. (2001). Good Governance. Telaah dari Dimensi, Akuntabilitas dan Kontrol Birokrasi Pada Era Desentralisasi dan Otonomi Daerah. Insan Cendikiya.

Zuhdiyaty, N., \& Kaluge, D. (2017). Analisis faktor faktor yang mempengaruhi kemiskinan di Indonesia selama lima tahun terakhir (Studi Kasus Pada 33 Provinsi). JIBEKA, 11(2), 2731. 